\title{
Late Godard and the Possibilities of Cinema
}


The publisher gratefully acknowledges the generous contribution to this book provided by the University of Pittsburgh. 


\title{
Late Godard and the Possibilities of Cinema
}

\author{
Daniel Morgan
}

甲ㅜ

UNIVERSITY OF CALIFORNIA PRESS

Berkeley Los Angeles London 
University of California Press, one of the most distinguished university presses in the United States, enriches lives around the world by advancing scholarship in the humanities, social sciences, and natural sciences. Its activities are supported by the UC Press Foundation and by philanthropic contributions from individuals and institutions. For more information, visit www.ucpress.edu.

University of California Press

Berkeley and Los Angeles, California

University of California Press, Ltd.

London, England

(C) 2013 by The Regents of the University of California

Library of Congress Cataloging-in-Publication Data

Morgan, Daniel, 1977-.

Late Godard and the possibilities of cinema / Daniel Morgan.

p. $\mathrm{cm}$.

Includes bibliographical references and index.

ISBN 978-0-520-27331-3 (cloth : alk. paper)

ISBN 978-0-520-27333-7 (pbk. : alk. paper)

1. Godard, Jean-Luc, 1930-Criticism and interpretation.

2. Motion pictures-Aesthetics. I. Title.

PN1998.3.G63M58 2013

$791.4302 ' 33092-\mathrm{dc} 23$

2012025816

Manufactured in the United States of America

$\begin{array}{llllllllll}22 & 21 & 20 & 19 & 18 & 17 & 16 & 15 & 14 & 13\end{array}$

$\begin{array}{llllllllll}10 & 9 & 8 & 7 & 6 & 5 & 4 & 3 & 2 & 1\end{array}$

In keeping with a commitment to support environmentally responsible and sustainable printing practices, UC Press has printed this book on 50-pound Enterprise, a 30\% post-consumer-waste, recycled, deinked fiber that is processed chlorine-free. It is acid-free and meets all ANsI/ NIsO (z 39.48) requirements. 
Is there anywhere a space where everything becomes light?

-F. W. J. SCHELLING 
This page intentionally left blank 